\title{
Evaluation of the External and Internal Quality Characteristics of Quail Eggs Produced in Benghazi
}

\author{
N. A. Salem* and B. A. Haj-Saeed \\ Department of Animal Production, Faculty of Agriculture, \\ University of Benghazi, Benghazi, Libya \\ *Corresponding author
}

\section{A B S T R A C T}

\begin{tabular}{l}
\hline Ke y w o r d s \\
$\begin{array}{l}\text { Quail eggs, Egg } \\
\text { shell quality, Egg } \\
\text { quality, Yolk } \\
\text { quality, Cholesterol } \\
\text { level }\end{array}$ \\
\hline Article Info \\
\hline $\begin{array}{l}\text { Accepted: } \\
\text { 15 May } 2020 \\
\text { Available Online: } \\
\text { 10 June } 2020\end{array}$ \\
\hline
\end{tabular}

The study aimed to assess the quality of egg shell, egg white and yolk for Japanese quail eggs produced in the city of Benghazi during the summer season of 2019 and to estimate the level of cholesterol in the yolk where a herd consisting of 100 birds was used at the age of 5 months. The results of this study indicate that eggs weigh $12.74 \mathrm{~g}$, with a factor of 78.53 and a volume of $12.21 \mathrm{~cm}^{3}$, representing the shell, whites and yolks in it 11.63 , 54.20 and $35.66 \%$, respectively. The shell of quail eggs weighs $1.29 \mathrm{~g}$ and is of a specific weight of 1.043 and the shell weight of each unit is a surface area of $50.59 \mathrm{~g} / \mathrm{cm}^{2}$ and a shell of $0.22 \mathrm{~mm}$ thick. The weight of quail egg white was $6.90 \mathrm{~g}$ and the white and Haugh unit was 49.70 and 72.44 , respectively. The yolk weight was $4.54 \mathrm{~g}$ with a guide shape of 0.44 and the $\mathrm{pH}$ of the egg and yolk was 8.89 and 6.30, respectively. One quail egg contains $46.58 \mathrm{mg}$ cholesterol, equivalent to $10.26 \mathrm{mg} / \mathrm{g}$ yolks. The results of this study indicate a low quality of egg components and a similar level of cholesterol in previous studies.

\section{Introduction}

Many countries of the world are trying to increase their production of animal protein by raising other types of poultry other than chicken, including quail, as breeding has become a common issue in the commercial poultry sector for meat and egg production because of its rapid growth and early sexual maturity and its high rate of egg production and its need for feed quantity and a small breeding area Very compared to other poultry (Thiyagasundaram, 1989; Kumari, 200).

Poultry eggs, including quail eggs, are foods of high value to humans because they are one of the best economic sources of high-quality protein, as they meet the human needs of essential amino acids as well as vitamins, minerals and fatty acids (Moura et al., 2010). 
Quail eggs are spherical and have different shell colors that vary from dark brown to blue to white with black or blue spots (Sezer and Tekelioglu, 2009; Taha, 2011; Alaşahan et $a l ., 2015)$ and quail eggs are approximately the size of chicken eggs (Panda and Singh, 1990) Quail lays 70-85\% of eggs between 17:00 to 09:00 (Choil et al., 2004; Petek, 2006).

Quail eggs do not differ from chicken eggs in their chemical composition (Panda and Singh, 1990; Tolik et al., 2014) The whole egg contains 73.80-74.60, 13.05-13.23, 10.8311.20, 1.10-1.13 and 0.41-1.03\% Moisture, Protein and Fat Ash and carbohydrates, respectively (Whiting, 1966; Tiwary and Panda, 1978; Stadelman et al., 1988)..

Genchev (2012) studied the components of amino acids in two strains of quail eggs, Pharaoh and Manchurian Golden, noting that the essential amino acids of the Pharaoh strain were 7.01, 6.72, and 7.54\%, and the Manchurian Golden strain was 6.92, 6.42, and $7.71 \%$ in whole eggs, eggs, and yolk on Respectively, without quail eggs, Choi et al., (2001) explained that quail egg fat is distributed to $36.4 \%$ of it as saturated fatty acids and the rest are polyunsaturated fatty acids representing mono, including $51.6 \%$ and multiple $121.0 \%$ and essential fatty acids represent a total of $10.9 \%$ of fatty acids The total cholesterol level in quail eggs ranges from 11.96 to $26.02 \mathrm{mg} / \mathrm{g}$ Saffar(Lepore and Marks, 1965; Bair and Marion, 1978; Bitman and Wood, 1980; Riad et al., 1981; Choi et al., 2001) depending on several factors including heredity (Washbunn and Nix, 1974; Sheridan et al., 1982) and the age of birds (Sheridan et al., 1982), the type of poultry (Bair and Marion, 1978; Bitman and Wood, 1980) and the single species strain (Sheridan et al., 1982; Han and Lee, 1992; Basmacioúlu and Ergül, 2005; Al-Zuhairi, 2010) and the breeding system (Basmacioúlu and Ergül,
2005) and poultry feeding (Salma et al., 2007; Yin et al., 2008; Mikulski et al., 2012).

The quality of the external and internal quail eggs are affected by several factors, the most important of which are the strain (Genchev, 2012; Hrnár et al., 2014; Chimezie et al., 2017; Hassan et al., 2017) and nutrition (Sathya and Murugaian, 2015; Sabir et al., 2016) and age (Yannakopoulos and TserveniGousi González, 1995: Wilkanowska and Kokoszyński, 2012) and storage time (Nepomuceno et al., 2014).

Studies of chicken eggs obtained the most share in the study on their quality and chemical composition, so this study aims to study the external quality (the shell) and the interior (whites and yolks) for Japanese quail eggs produced in the outskirts of Benghazi.

\section{Materials and Methods}

Eggs used: In this research, eggs were used from productive farms in different suburbs of the city of Benghazi during the summer of 2019, where white and brown eggs were taken from the productive fields of intensive breeding in closed halls while raising other types of poultry was domestic.

The eggs produced were transferred to the Animal Production Laboratory of the Faculty of Agriculture - Salouq, and measurements were made regarding the quality of the external eggs (shell) and the interior (whites and yolks).

Measurements: The egg (EW) was weighted to the nearest 4 decimal places $(0.0001)$ in a digital scale and the diameter and length of the egg to estimate the egg shape index (Anderson et al., 2004). The size of the egg was also mathematically estimated for use in estimating the specific weight of the shell (Dorji et al., 2014). 
The shell was weighed after the egg was broken and washed with water to remove the effects of the egg and its dryness. From that, the ratio of the shell was estimated. Then, the thickness of the shell was estimated by a micrometer device two days after breaking it, taking two measurements from different areas. The surface area of the shell was also estimated (Thomson et al., 1985). (Alkan et al., 2013) The crust index was estimated according to Ahmed et al., (2005).

The weight of the egg was calculated from subtracting the weight of the yolk and the shell from the egg weight. From it, the ratio of the egg was estimated. To estimate the quality of the egg, the egg was broken on a flat surface near it. The egg height was measured from 3 different areas and the rate was taken. From these measurements, the albumin index and the Haugh index were calculated. unit) on the day after storing eggs at temperatures of 5-10C to allow room for egg contents to remain and for a thick egg to take its full gelatinous texture to facilitate the measurement process according to the following equations (Stadelman and Cotterill, 1995):

\section{Egg white index}

$$
\left(100-{ }^{0.37} W 30\right)-\frac{H}{\sqrt{G}}
$$

\section{Haughunit}

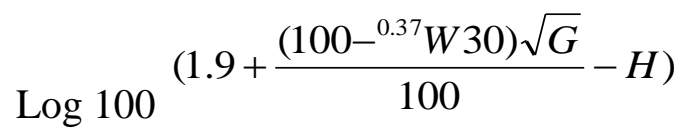

Where $\mathrm{H}=$ egg white $(\mathrm{mm}) ; \mathrm{G}=$ constant equal to $32.2 ; \mathrm{W}=$ egg weight (g.)

The white egg and yolk $\mathrm{pH}$ were measured using a type device after dilution of samples with 5 volumes with distilled water, stirred and mixed with a glass rod during the measurement (Shang et al., 2004).

The egg is broken and the egg is discarded as much as possible, then the yolk and the egg containing it are placed on the filter paper and moved in different directions so that the rest of the egg is absorbed on the filter paper and the yolk is placed on a petri dish and weighed (the yolk membrane maintains the contents of the yolk because it is strong and does not tear) and from it The yolk ratio was estimated, and because the shape of the yolk is determined by its height and diameter, the yolk index was used to express its shape (Keener et al., 2006).

The method mentioned by Francy and Elias (1968) was used to estimate the cholesterol in the yolk with some adjustments (Al-Obaidi, 1999) using a color ferric chloride solution detector and optical absorbance reading at a wavelength of $560 \mathrm{~nm}$ with the JENWAY6300 optical spectrometer and the cholesterol concentration was estimated from The standard curve for cholesterol.

\section{Results and Discussion}

Table (1) shows the external characteristics of the whole egg, as the average egg weight was $12.74 \mathrm{~g}$, and the egg shape factor was $78.53 \%$ for the egg weight, this weight is close to the weight of the Japanese quail eggs produced for eggs and meat in the study of Hrncar et al., (2014), where the average weight The eggs in both strains are 11.48 and $13.06 \mathrm{~g}$, respectively.

The results of this study are consistent with the results of Yannakopoulos, Tserveni-Gousi (1986), Wilkanowska, and Kokoszyński (2012). The eggs weights in these two studies reached 12.95 and 12.2 gm respectively, but they outperform the egg weight in the González (1995) study, which showed that 
The weight of an egg at the age of 5 months reached $10.79 \mathrm{~g}$ and did not differ from that after 9 months to reach $10.68 \mathrm{~g}$.

The physical properties of eggs change with age (Yannakopoulos and Tserveni-Gousi, 1986). As for egg weight, it gradually increases from the age of sexual maturity up to 5 months.

The differences between this study and previous studies are due to the different methods of feeding, environment, strain and age.The egg shape coefficient is expressed according to the classification based on the coefficient and guide of the egg (Duman et al., 2010).

The eggs are classified into three classes: sharp end eggs, standard eggs and round eggs when the egg shape factor is less than 72, 7276 and more than 76, respectively. Quail eggs in this study are classified as round eggs because the egg shape factor falls within the ranges of the circular eggs, The results of this study were consistent with the results of Hrncar et al., (2014) (76.70 and 78.18\% for eggs and meat strains respectively) and Genchev (2012) (77.04 and 77.32\% in the Manchunan Golden and Pharaoh strains respectively).

The weights of the three components are egg shells, egg whites and yolks in quail eggs are $1.29,6.90$ and $4.54 \mathrm{~g}$ which represent 11.63, 54.20 and $35.66 \%$ of the total egg, respectively (Table 2).

The results of this study differ from the study of Moura et al., (2010) who observed that the weights of the eggshell, egg white, and yolk components were $0.96,7.12$, and $4.00 \mathrm{~g}$, which represented 7.93, 58.94, and 33.14\%, respectively, since the height of the shell weight was observed in this study from that study.
Which led to a high percentage at the expense of eggs and yolk, knowing that the weight of the egg in the two studies is close (12.74 compared to $12.25 \mathrm{~g}$ ), and these differences may be due to feeding and age of birds.

Hrnar et al., (2014) found approximate results for this study where weights and proportions of shell, egg and yolk were $1.02 ; 8.88$ and $6.75 ; 58.78$ and $3.72 \mathrm{~g} ; 32.43 \%$ represents $11.48 \mathrm{~g}$ which is egg weight.

Table (3) shows the specific characteristics of quail egg shells, as the thickness of the shell does not differ in this study from the studies of Hrnar et al., (2014) and González (1995), Sathya and Murugaian (2015) (0.22 compared to $0.23,0.219$ and $0.20 \mathrm{~mm}$ )respectively, but it outperformed the values obtained by Yannakopoulos, Tserveni-Gousi (1986) and Genchev (2012) that were of the same egg shell thickness of the same age as 0.168 and 0.201-0.207 $\mathrm{mm}$, respectively and on the other hand they were lower than the shell thickness in Chimezie (2017) study of 0.27 $\mathrm{mm}$ in white, black and brown Japanese quail.

When expressing the quality of the egg shell, through its specific weight, which is an indirect measure of the thickness of the egg shell, it becomes clear that the quality of the egg shell is $1.043 \mathrm{~g} / \mathrm{cm}^{3}$, which is less than the specific weight of the egg shell in the studies of both Yannakopoulos and TserveniGousi. (1986) and Moura et al., (2010) who observed that the specific egg weight was 1.054-1.081 and $1.074 \mathrm{~g} / \mathrm{cm}^{3}$, respectively, and these differences can be attributed to strain, nutrition, age and method of measurement.

Table (4) shows the specific characteristics of quail eggs which indicate a low quality of eggs through the values of white evidence (49.70) and a unit of (72.44) low. The reason for this can be attributed mainly to poor egg 
storage conditions until it reaches the college laboratory for analysis and measurements, which The liquidity cause of the gelatinous texture of the egg whites, which caused the decrease in its height, which depends on it in calculating both the egg white index and the Haugh unit.
Hrnar et al., (2014) found that the unit of egg whites in the Japanese quail-breed strain was 87.28, higher than the Haughunit and quail eggs in this study by $20.5 \%$, the same increase observed by Gopinger et al., (2016) and Hassan et al., (2017).

Table.1 Weight, size and coefficient of poultry egg shape (Mean \pm SE)

\begin{tabular}{|l|c|}
\hline Measurements & Mean \pm SE \\
\hline Egg weight $(\mathbf{g})$ & $12.74 \pm 0.45$ \\
\hline Egg length $(\mathbf{m m})$ & $33.86 \pm 0.65$ \\
\hline Egg width $(\mathbf{m m})$ & $26.59 \pm 0.33$ \\
\hline Egg shape factor $(\boldsymbol{\%})$ & $78.53 \pm 1.20$ \\
\hline Egg size $(\mathbf{c m} 3)$ & $12.21 \pm 0.50$ \\
\hline
\end{tabular}

Table.2 Weight and proportions of local chicken egg ingredients (Mean \pm SE)

\begin{tabular}{|l|l|l|l|}
\hline Component & Egg Shells & Egg Whites & Yolks \\
\hline Weight (g) & $1.29 \pm 0.05$ & $6.90 \pm 0.20$ & $4.54 \pm 0.64$ \\
\hline The ratio (\%) & $11.63 \pm 0.57$ & $54.20 \pm 3.07$ & $35.66 \pm 3.32$ \\
\hline
\end{tabular}

Table.3The quality of the egg shell in the domestic chicken (Mean \pm SE)

\begin{tabular}{|c|c|}
\hline Quality & Mean \\
\hline egg shells thickness $(\mathbf{m m})$ & $0.02 \pm 0.22$ \\
\hline Specific weight $(\mathbf{g} / \mathbf{c m} 3)$ & $0.03 \pm 1.043$ \\
\hline Surface area $(\mathbf{c m})$ & $0.60 \pm 25.50$ \\
\hline Weight $/$ unit area $(\mathbf{g} / \mathbf{c m} 2)$ & $0.002 \pm 50.59$ \\
\hline
\end{tabular}

Table.4 Quality of egg whites in local chicken (Mean \pm SE)

\begin{tabular}{|l|c|}
\hline Quality & Mean \\
\hline Egg Whites Thickness $(\mathbf{M m})$ & $2.55 \pm 0.24$ \\
\hline Egg Whites Index & $49.70 \pm 5.69$ \\
\hline Haugh Unit & $72.44 \pm 2.56$ \\
\hline pH & $8.89 \pm 0.04$ \\
\hline
\end{tabular}

Table.5 Quality of egg yolk in local chicken (Mean \pm SE)

\begin{tabular}{|r|c|c|}
\hline Quality & Yolk index & pH \\
\hline Med & $0.44 \pm 0.02$ & $6.30 \pm 0.15$ \\
\hline
\end{tabular}


Figure.1 The yolk and egg content of cholesterol

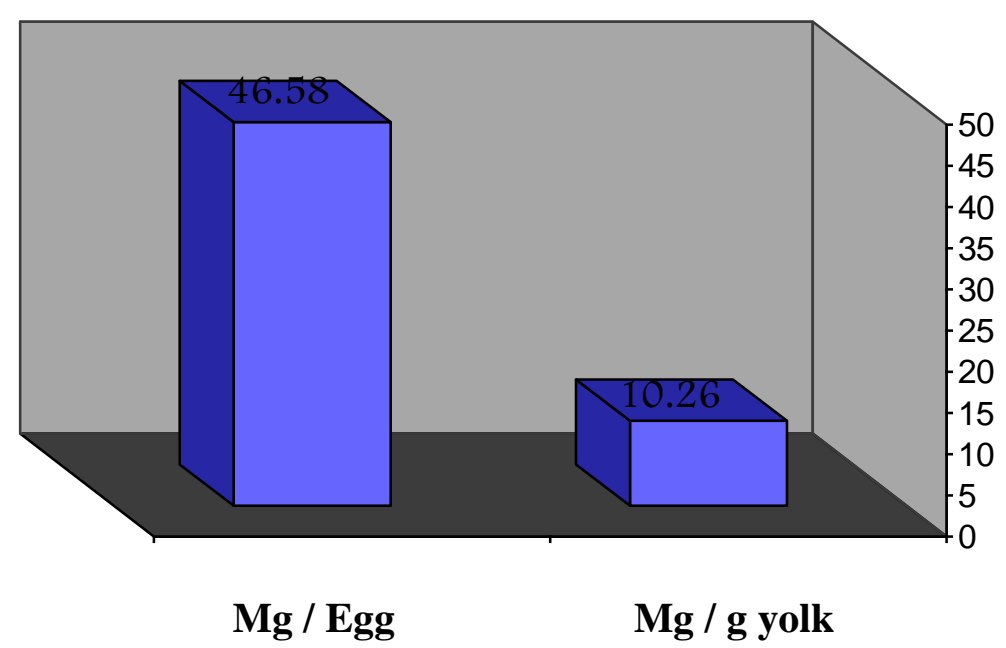

Table (5) indicates a relatively low yolk quality, as the yolk index is 0.44 and the yolk $\mathrm{pH}$ has reached 6.24.

The values of the yolk index are far from those of 47.96-50.96 (González, 1995; Hassan et al., 2017) but are close to what Genchev (2012) found in the Pharaoh and Manchunan Golden strains of 0.45 in both and the results of this study are consistent with the results obtained by Wilkanowska And Kokoszyński (2012) conducted on the Pharaoh quail strain at the age of 18 weeks where the yolk coefficient was 0.449 except that it differs from the values obtained at 23 weeks at the age of 0.47 .

The deterioration in the quality of the yolk may be due to poor egg storage conditions after delivery, which causes the elasticity of the yolk membrane, its expansion and increase in its area, and in other words, the yolk diameter and then a decrease in the yolk guide.

Figure (1) shows the cholesterol quail eggs content as one egg contains $46.58 \mathrm{mg}$ cholesterol, with $3.66 \mathrm{mg} / \mathrm{g}$ eggs and 10.26 $\mathrm{mg} / \mathrm{g}$ yolk.
The cholesterol results in this study were less than the concentration of cholesterol in quail eggs in the Pharaoh and Manchunan Golden strains, where the cholesterol concentration was 15.94 and $13.63 \mathrm{mg} / \mathrm{g}$ yolk, respectively (Genchev, 2012), as was the case in the study of Choi et al.,(2001), which found that the concentration Cholesterol in Japanese quail eggs was $12.96 \mathrm{mg} / \mathrm{g}$ yolk, but the cholesterol concentration in one egg was $10.5 \%$ higher in this study (46.58 compared to $42.15 \mathrm{mg} / \mathrm{egg}$ ). The cholesterol levels in Japanese quail eggs in the study of Bair and Marion (1978) The highest comparison with this study was $14.3 \mathrm{mg} / \mathrm{g}$ yolk, and the same applies to the contents of yolk quail eggs American and Japanese in Maurice et al., (1994), where the cholesterol concentration was 13.2 and $14.7 \mathrm{mg} / \mathrm{g}$ yolk, respectively, but the expression of the concentration for each egg did not cause a difference between that study and the current study (47 and 45 compared to $46.58 \mathrm{mg}$ / eggs, respectively). While the concentration when expressed in units of mg per kilogram of whole egg in that study was higher compared to the current study (5.74 and 4.95 compared to $3.66 \mathrm{mg} / \mathrm{g}$ eggs). 
These differences may be due to the different conditions of breeding, age, strain, nutrition, egg weight, yolk, and estimation method.

There is a variation in the cholesterol concentration between quail eggs in this study and the chicken eggs most consumed by humans, as it appears that its higher concentration in chicken eggs compared to quail eggs in the study of Beyer and Jensen (1992) and found that the cholesterol concentration in chicken eggs at the age of 20 weeks of the production period was $17.7 \mathrm{mg} /$ g yolk. In the Liu et al., (2010) study, the cholesterol concentration in chicken eggs at the age of 6 was $7.0 \mathrm{mg} / \mathrm{g}$.

\section{References}

Ahmed, A. M. H., A. B. Rodriguez-Navarro, M. L. Vidal, J. Gautron, J. M. Garcia-Ruiz, and Y. Nys. 2005. Changes in eggshell mechanical properties, crystallographic texture and in matrix proteins induced by moult in hens. Br. Poult. Sci. 46:268-279.

Alaşahan, S., G. Ç. Akpınar, S. Canoğulları, and M. Baylan. 2015. Determination of some external and internal quality traits of Japanese quail (Coturnix coturnix japonica) eggs on the basis of eggshell colour and spot colour. Eurasian J. Vet. Sci. 31:235-241.

Alkan, S., K. Karaba:, A. Galic, T. Karasli, and M. S. Balcio:lu. 2010. Effects of selection for body weight and egg production on egg quality traits in Japanese quails (Coturnix coturnix japonica) of different lines and relationships between these traits. Kafkas Universitesi Veteriner Fakultesi Dergisi 16:239-244.

Al-Obaidi, Fares Abdul Ali Mahdi. 1999. Assessment of the qualitative and chemical characteristics of Japanese quail eggs. PhD. College of Agriculture University of Baghdad.

Al-Zuhairi, Zahira Abdul-Jabbar. 2010. Study and comparison of the chemical properties of different types of table eggs consumed in Al-Diwaniyah city. AlQadisiyah Journal of Veterinary Science 9: 38-42.

Anderson, K. E., J. B. Tharrington, P. A. Curtis, and F. T. Jones. 2004. Shell characteristics of eggs from historic strains of single comb white leghorn chickens and relationship of egg shape to shell strength. International J. Poult. Sci. 3:17-19.

Bair, C. W. and W. W. Marion. 1978. Yolk cholesterol in eggs from various avian species. Poult. Sci. 57:1260-1265.

Basmacioúlu, H., and M. Ergül. 2005. Research on the factors affecting cholesterol content and some other characteristics of eggs in laying hens. The effects of genotype and rearing system. Turk J. Vet. Anim. Sci. 29:157-164.

Beyer, R. S., and L. S. Jensen. 1992. Cholesterol concentration of egg yolk and blood plasma and performance of laying hens as influenced by dietary $\alpha$ ketoisocaproic acid. Poult. Sci. 71:120127.

Bitman, J. and D. L. Wood. 1980. Cholesterol and cholesteryl esters of eggs from various avian species. Poult. Sci. 59: 2014-2023.

Chimezie, V. O., T. R. Fayeye, K. L. Ayorinde, and A. Adebunmi. 2017. Phenotypic correlations between egg weight and some egg quality traits in three varieties of Japanese quail (Coturnix coturnix japonica). Agrosearch 17:44-53.

Choi, J. H., H. Namkung and I. K. Paik. 2004. Feed consumption pattern of laying hens in relation to time of oviposition. AsianAust. J. Anim. Sci. 17: 371-373.

Choi, S. H., K. T. Song, and H. R. Oh. 2001. Cholesterol contents and fatty acid composition of chukar, pheasant, guinea fowl and quail egg yolk. Asian-Aust. J. Anim. Sci. 14:831-836.

Dorji, N. 2014. Assessment of storage and temperature on egg physical qualities for peak production in Hyline chickens. Iranian J. Appl. Anim. Sci. 4: 173-178.

Frany, R. J. and A. Elias. 1968. Serum 
cholesterol measurement based on Ethanol extraction and Ferric chloride sulfuric acid. Cli. Chem. Acta. 2:255-263.

Genchev, A. 2012. Quality and composition of Japanese quail eggs (Coturnix japonica). Trakia J. Sci. 10:91-101.

Gonzalez, M. 1995. Influence of age on physical traits of Japanese quail (Coturnix coturnix japonica) eggs. Annales De Zootechnie 44:307312.

Gopinger, E., C. Bavaresco, V. Ziegler, J. S. Lemes, D. C. N. Lopes, M. C. Elias, and E.G. Xavier. 2016. Performance, egg quality, and sensory analysis of the eggs of quails fed whole rice bran stabilized with organic acids and stored for different amounts of time. Can. J. Anim. Sci. 96:128-134.

Han, C. K. and N. H. Lee. 1992. Yolk cholesterol content in eggs from the major domestic strains of breeding hen. AsianAust. J. Anim. Sci. 5:461-464.

Hassan, A. M., D. A. Mohammed, K. N. Hussein, and S. H. Hussen. 2017. Comparison among three lines of quail for egg quality characters. Sci. J. University of Zakho 5:296-300.

Hrnčár, C. E. Hanusová, A. Hanus, and J. Bujko. 2014. Effect of genotype on egg quality characteristics of Japanese quail (Coturnix japonica). Slovak J. Anim. Sci. 47:6-11.

Keener, K. M., K. C. McAvoy, J. B. Foegeding, P. A. Curtis, K. E. Anderson, and J. A. Osborne. 2006. Effect of testing temperature on internal egg quality measurements. Poult. Sci. 85:550-555.

Kumar, A., S. M. H. Akhtar, S. B. Verma, and K. G. Mandal. 2000. Influence of age, body weight, egg weight, clutch size and pause on egg production in Japanese quails. Indian J. Anim. Health 39:82-84.

Liu, X., H. L. Zhao, S. Thiessen, J. D. House, and P. J. H. Jones. 2010. Effect of plant sterol-enriched diets on plasma and egg yolk cholesterol concentrations and cholesterol metabolism in laying hens. Poult. Sci. 89:270-275.

Maurice, D. V., S. F. Lightsey, K. T. Hsu, T. G.
Gayiord, and R. V. Reddy. 1994. Cholesterol in eggs from different species of poultry determined by capillary GLC. Food Chemistry 50:367-372.

Mikulski, D., J. Jankowski, J. Naczmanski, M. Mikulska, and V. Demey. 2012. Effects of dietary probiotic (Pediococcus acidilactici) supplementation on performance, nutrient digestibility, egg traits, egg yolk cholesterol, and fatty acid profile in laying hens. Poult. Sci. 91:2691-2700.

Monira, K. N., M. Salahuddin, and G. Miah. 2003. Effect of breed and holding period on egg quality characteristics of chicken. International J. Poult. Sci. 2:261-263.

Nepomuceno, R. C., P. H. Watanabe, E. R. Freitas, C. E. B. Cruz, M. S. M. Peixoto, and M. L. De Sousa. 2014. Quality of quail eggs at different times of storage. Cienc. anim. bras., Goiânia, 15:409-413.

Panda, B., and R. P. Singh. 1990. Developments in processing quail meat and eggs. World's Poult. Sci. J. 46:219-234.

Petek, M. 2006. Effect of feeding time on laying and reproductive performance of pharaoh quail (Coturnix coturnix Pharaoh) housed in different cage systems. Asian-Aust. J. Anim. Sci. 19:6771.

Riad, S. A., M. A. M. Kicka, M. A. Osman, and G. A. R. Kamar. 1981. Yolk cholesterol in eggs from various avian species. Egyptian J. Anim. Prod. 21: 51-55.

Sabir, P. S., S. Dh. Mohammad, B. F. Sulaiman, S. Y. Al-Sardary, and A. A. Mustafa. 2016. Effect of some feed additives on quality and chemical composition of local quails eggs. International J. Advances in Sci. Engineering and Technology 4:194197.

Salma, U., A. G. Miah, K. M. A. Tareq, T. Maki, and H. Tsujii. 2007. Effect of Dietary Rhodobacter capsulatus on eggyolk cholesterol and laying hen performance. Poult. Sci. 86:714-719.

Sathya, C., and P. Murugaian. 2015. Effect of dietary supplementation of probiotic and Curculigo orchioides rhizome powder on 
egg quality parameters and biochemical composition of Japanese quail (Coturnix coturnix japonica). International J. Advances in Pharmacy, Biology and Chemistry 4:162-170.

Sezer M, Tekelioglu O, 2009. Quantification of Japanese quail eggshell colour by image analysis. Biol Res 42:99-105.

Shang, X. G., F. L. Wang, D. F. Li, J. D. Yin, and J. Y. Li. 2004. Effects of dietary conjugated linoleic acid on the productivity of laying hens and egg quality during refrigerated storage. Poult. Sci. 83:1688-1695.

Sheridan, A. K., S. M. Hamphris and P. J. Nicholls. 1982. The cholesterol content of eggs produced by Australian egg laying strains. British Poult. Sci. 23:569-575.

Stadelman, W. J., and O. J. Cotterill. 1995. Egg Science and Technology. 2nd ed. AVI Publishing Company. INC. Westport, Connecticut.

Taha AE, 2011. Analyzing of quail eggs hatchability, quality embryonic mortality and malpositions in relation to their shell colors. Online J Anim and Feed Res $1: 267-273$.

Thiyagasundaram, T. S. 1989. Comparative egg production efficiency of chickens, ducks and quails. Poult. International 28: 60

Thompson, B. K., R. M. G. Hamilton, and A. A. Grunder. 1985. The relationship between laboratory measures of egg shell quality and breakage in commercial egg washing and candling equipment. Poult. Sci. 64:901-909.

Tiwary, K. S. and B. Panda. 1978. Production and quality characteristics of quail eggs. Indian J. Poult. Sci. 13:27-32.

Tolik, D., E. po£awska, A. Charuta, S. Nowaczewski, and R. Cooper. 2014. Characteristics of egg parts, chemical composition and nutritive value of japanese quail eggs - a review. Folia Biologica (Kraków) 62:287-292.

Washburn, K. W. and D. F. Nix. 1974. Genetic basis of yolk cholesterol content. Poult. Sci. 53:109-115.

Whiting, M. G. 1966. The composition of eggs of Japanese quail. Quail Quarterly 3:75

Wilkanowska, A., and D. Kokoszy:ski. 2012. Layer age and quality of pharaoh quail eggs. J. Central European Agriculture $13: 10-21$

Yannakopoulos, A. L., and A. S. Tserveni:Gousi. $\quad 1986 . \quad$ Quality characteristics of quail eggs. Br. Poult. Sci. 27:171-176

Yin, J. D., X. G. Shang, D. F. Li, F. L. Wang, Y. F. Guan, and Z. Y. Wang. 2008. Effects of dietary conjugated linoleic acid on the fatty acid profile and cholesterol content of egg yolks from different breeds of layers. Poult. Sci. 87:284-290.

\section{How to cite this article:}

Salem, N. A. and Haj-Saeed, B. A. 2020. Evaluation of the External and Internal Quality Characteristics of Quail Eggs Produced in Benghazi. Int.J.Curr.Microbiol.App.Sci. 9(06): 750758. doi: https://doi.org/10.20546/ijcmas.2020.906.096 